A análise e o arquivo

Élisabeth Roudinesco Rio de Janeiro: Jorge Zahar, 2006, 80 págs.

\title{
A análise, o arquivo
}

Paulo J osé Carvalho da Silva

O pequeno livro de Élizabeth Roudinesco, A análise e o arquivo, recém-publicado pela editora Jorge Zahar, interessa não somente ao historiador e ao psicanalista, mas também a todos que se dedicam à pesquisa em ciências humanas. O pensamento da historiadora e psicanalista francesa é bastante conhecido do leitor brasileiro, por meio de várias publicações, entre outras: História da psicanálise na França. 2 vols (Jorge Zahar, 1988); Jacques Lacan: esboço de uma vida, história de um sistema de pensamento (Companhia das Letras, 1993); Dicionário de psicanálise (com Michel Plon, Jorge Zahar, 1998); A família em desordem (Jorge Zahar 2003).

Trata-se agora da tradução de L'analyse, l'archive, três conferências pronunciadas no auditório da Bibliothèque Nationale de France, em Paris, e publicadas pela editora da mesma biblioteca em 2001: “O poder do arquivo"; "Jacques Lacan: o estádio do espelho" e "O culto de si e as novas formas de sofrimentos psíquicos”. Logo de entrada, na primeira das interligadas exposições, a autora adverte que suas considerações não se reduzem a uma psicanálise do arquivo, tampouco a uma descrição do arquivo da psicanálise.

De fato, a originalidade de suas conferências reside na reflexão competente sobre diferentes posições diante do arquivo e suas implicações para a história da psicanálise, sem com isso misturar os campos da análise dos vestígios do passado e da escuta do inconsciente. A opção do tradutor 
em usar a conjunção coordenativa aditiva ao invés da vírgula do original francês, talvez em nome do bom português, mascara levemente uma sutileza presente no título, que será desenvolvida ao longo do livro.

Roudinesco descreve a tensão, vivida na escrita da história, entre a fantasia do arquivo total e, portanto, transformado em saber absoluto que anula a história como criação e o arquivo vazio que, por sua vez, não forneceria as fontes primárias, única garantia de que a história não é pura projeção do historiador.

Na primeira conferência, partindo da constatação de que o arquivo é condição da história, Roudinesco analisa como a sacralização dos arquivos de Freud, sob o controle da IPA e interditados aos historiadores profissionais, colaborou para a proliferação de discursos que, baseados em uma interpretação delirante do excesso de arquivo, tornaram Freud um personagem diabólico e empreenderam uma desmontagem da própria psicanálise. Ela lembra também que o desenraizamento da obra de Lacan dar-se-ia, em parte, por seu esforço em se projetar num presente interminável por meio de um ensino essencialmente oral e, em parte, pelo controle jurídico e interpretativo que seu genro exerce sobre os restos de um arquivo quase vazio.

A segunda conferência reconstrói o processo de elaboração da teoria lacaniana do estádio do espelho, a partir de um arquivo suprimido, já que Lacan não entregara seu primeiro texto sobre o assunto para a publicação das atas do XIV Congresso da IPA, em Marienbad. Ao investigar as fontes explícitas e omitidas que balizaram o pensamento de Lacan entre 1936 e 1949, data do Congresso de Zurique, no qual ele expõe sua nova conferência sobre o estádio do espelho, Roudinesco não apenas relata episódios da história da psicanálise lacaniana; ela mostra, por meio destes, como Lacan, após ter sofrido um duro golpe em seu narcisismo devido a uma entrada frustrante na cena do movimento psicanalítico, apurou sua visão de homem e sua escuta das paixões da alma.

A terceira parte do livro examina a expansão da cultura do narcisismo nas sociedades industrializadas contemporâneas e demonstra como essa confiança nos sistemas adaptativos, ao mesmo tempo em que promete uma felicidade jamais vivida, engendra novos sofrimentos psíquicos, suscita classificações aberrantes e move o mercado de terapias do eu. Roudinesco adverte que este culto ao arquivo de si é o negativo da psicanálise e da história na medida em que representa o abandono da idéia de uma subjetividade rebelde e nega o peso do passado na constituição dessa subjetividade.

Freud afirmou em 1917, em “Uma dificuldade da psicanálise”, que haveria uma resistência emocional à psicanálise porque esta questionava a ilusão narcísica da soberania do eu ao revelar a realidade pulsional da alma humana. Não haveria hoje, inclusive entre toda sorte de herdeiros dos pais da psicanálise, uma resistência à história por razões da ordem do narcisismo? 
Enquanto historiadora e psicanalista, Roudinesco faz uma defesa apaixonada da psicanálise e escreve uma história crítica, distinta da apologia cerimonial dos grandes homens do passado, muito comum quando se pretende preservar a autoridade ou enaltecer mestres e predecessores, por motivos, digamos, narcisistas. Ela recoloca a psicanálise no tempo e no espaço, dando dignidade a seus autores e alicerce às idéias.

Michel de Certeau, em uma grande ausência nas referências da autora, Histoire et psychanalyse entre sicence et fiction, originalmente publicada em 1986 pela University of Minnesota, em 1987 pela Gallimard, em 2002 revisto e aumentado por Luce Giard, sublinha o caráter subversivo da história e da psicanálise que, a despeito da suposta objetividade e generalização científica, comprometem-se com a investigação de uma verdade singular.

Aliás, é o compromisso com a verdade que deveria preencher o silêncio entre o arquivo e a análise e evitar a instituição de novos tabus nas escolas psicanalíticas. As conferências de Roudinesco, feitas nas dependências de um dos maiores arquivos do mundo, lembraram-me de uma cena ilustrativa das armadilhas do desejo perante as fontes do saber. Em certa feita, um pesquisador atravessou a monumental sala de leitura da Biblioteca Apostólica Vaticana fazendo os silenciosos estudiosos repararem que ele precisava de um objeto para abrir as páginas intactas de um antigo livro ainda fechado. A postura triunfante do pesquisador deflorador de livros imaculados revelava seu gozo em ter acesso pela primeira vez ao que ficou guardado esperando para que viesse finalmente à luz por meio de suas mãos hábeis e olhos treinados. Mas, afinal, qual é a função de um livro nunca lido? E mais importante ainda: qual é o desejo que move a descida aos fundos dos arquivos? A análise e o arquivo aponta algumas preciosas respostas. 